Available online at GSC Online Press Directory

GSC Biological and Pharmaceutical Sciences

e-ISSN: 2581-3250, CODEN (USA): GBPSC2

Journal homepage: https://www.gsconlinepress.com/journals/gscbps

(REVIEW ARTICLE)

\title{
Bergenia ciliata as antibacterial agent
}

Sayed Suliman Shah ${ }^{1, \dagger}$, Dawood Shah ${ }^{1}$, Ibrahim Khan ${ }^{2, *}, \dagger$, Muhammad Ilyas ${ }^{3}$, Sohail Ahmad Jan ${ }^{4}$ and Imran Khan ${ }^{1}$

${ }_{1}^{1}$ Department of Chemistry, Government Degree College No.2 Mardan, Abdul Wali Khan University Mardan, KP Pakistan.

${ }^{2}$ Department of Biotechnology, School of Life Sciences and Technology, University of Electronic Science and Technology of China.

${ }^{3}$ Department of Botany, Bacha Khan University Charsadda, KP Pakistan.

${ }^{4}$ Department of Biotechnology, Hazara University Mansehra, KP Pakistan.

tFirst and third author contributed equally to this work.

Publication history: Received on 28 June 2020; ; revised on 03 August 2020; accepted on 05 August 2020

Article DOI: https://doi.org/10.30574/gscbps.2020.12.2.0206

\begin{abstract}
The search for alternatives to combat antibiotics has been increased due to the upsurge in cases of antibiotic-resistant pathogens that has become a global phenomenon which threatens the human health. Medicinal plants provide multiple health benefits because these plants contain bioactive phytochemicals that are used in medicines as alternatives to various ailments of human beings. Bergenia ciliata is a perennial herb belongs to the family Saxifragaceae that consists of about 30 genera and 580 species worldwide. It has large, evergreen and leathery leaves with the pink to dark purple flowers and has various traditional and modern medical uses. This plant is considered is one of the most effective antibacterial agents. The present review emphasizes the antibacterial potential of Bergenia ciliata by compiling various researches and fragmented information. The most important phytochemicals derived from Bergenia ciliata launched on the pharmaceutical market are also discussed. This attempt will help the researchers to develop and synthesize new antibacterial drugs from Bergenia ciliata against drug-resistive pathogens.
\end{abstract}

Keywords: Bergenia ciliata; Antibacterial agent; Drug-resistive pathogens; Pharmacology; Bioactive compounds

\section{Introduction}

The interrelation of human beings with their surrounding herbs and medicinal plants draws its roots to the ancient civilizations [1]. Approximately 270,000 plant species are discovered till present time, while the existence of 400,000 plant species is possible in mother earth [2,3]. Plants are nature's gift to the humans as they are the main source of many bioactive substances and modern as well as traditional drugs [4]. Approximately 35,000 to 70,000 plant species are used for medicines in the world and about 80 percent of world's population used medicinal plants for the treatment of various diseases i.e. arthritis, diabetes, eye infection, loss of hair, loose motion, skin disease, abortion, kidney stone, cough, hyper tension, stomach diseases and loss of alertness etc. [5]. Plants are the main source of medicinal compounds. These medicinal compounds, which provide a great help in the discovery of new medicines, isolated from plants are being studied by many researchers worldwide for their various medicinal activities [6].

Bergenia ciliata (winter begonia or hairy bergenia) is a perennial herb belongs to the family Saxifragaceae which consists of about 30 genera and 580 species worldwide [7]. This plant is 30-60 cm in height and has large, evergreen and leathery leaves with pink to dark purple flowers [8]. Family Saxifragaceae has various biological properties including antibacterial, antiviral, antioxidant, anti-ulcer, anti-diabetic, analgesic, anti-plasmodial, antitumor, antitussive activity, antineoplastic, diuretic and anti-inflammatory properties [9]. Bergenia ciliata is considered as a miracle

\footnotetext{
* Corresponding author: Khan Ibrahim E-mail: ibrahimkhan.qau@yahoo.com
} 
herb due to its use in treatment of many diseases viz; gastrointestinal problems, malaria and kidney stone etc. [10]. This plant is found between altitudes of 800-3000 m in Pakistan (mainly in Northern areas), Afghanistan, South Tibet, India (mainly in Himalayas and West Bengal), Bhutan, Meghalaya, Bhutan and Nepal [11,12]. Bergenia ciliata contains various phytochemicals viz; tannins, metarbin, terpenoids, mucilage, bergenin, flavonoids, sitoindoside, steroids, saponins, afzelechin, coumarins, gallic acid, tannic acid, paashanolactone, glucosides, quercitin, albumen and mineral salts [13]. Generally there are about 58 different phytochemicals present in Bergenia ciliata species of which some are categorized into 11 categories viz; alcohols, fatty acids, phenols, carboxylic acids, terpenoids, flavonoids, glycosides, nitro compounds, sterol, cinnamic acid and volatile organic compounds [10].

The innovation of antibiotics is the most important discovery in the $20^{\text {th }}$ century which has helped the human being in his everlasting battle against pathogens. But some species of pathogens had developed a significant resistance against the discovered antibiotics [14]. An utmost focus of contemporary medicine is the search for new strategies and substances to combat infectious diseases. This problem is very staid because many bacteria are very resistant to antibacterial drugs and leads to difficulty in treatment of infectious diseases. For example, Staphylococcus aureus, a Gram-positive, round-shaped bacterium, is highly resistant to antibiotics [15]. Such a resistance of microorganisms towards antibiotics causes approximately 25, 000 deaths per year in the European Union and about 23, 000 deaths in the USA. This problem is approaching towards more dangerous levels due to the scarcity of development of new antibiotics as over the past twenty five years only two classes of antibiotics viz; lipopeptides and oxazolidinones have been developed $[16,17]$. The only solution for this problem is the synthesis and discoveries of new antibacterial and other compounds to combat the resistance of pathogens against the antibiotics. Therefore, it is essential to develop and synthesis new antibiotics to control the resistance of pathogens. Due to the great importance of antibacterial drugs developed and synthesized from plants we gather the utmost fragmented literature about antibacterial activities of Bergenia ciliata and its important phytochemicals. Moreover, this review will help the researchers across the world to develop new antibacterial drugs from Bergenia ciliata against the resistive pathogens.

\section{Bergenia ciliata in traditional medicines}

Traditional medicinal system has been utilized since prehistoric times and draws its roots to ancient civilization. About 2500 plant species have medicinal value and about 6000 plants have been recognized to be used in traditional, folk and herbal medicine [18]. Bergenia ciliata is an attractive medicinal plant which attracts many researchers due to various medicinal activities. It is also used in traditional medicines for the treatment of many diseases i.e. skin diseases, muscular/skeletal disorders, pulmonary infections, gastrointestinal infections, fever, eye diseases ,worm infection , diarrhea, respiratory diseases, renal disorders, fever, oral infections, cancer, and gynecological disorders (Figure 1) [7]. Traditional healers used it mainly in the form of powder. Juice of dried rhizome of Bergenia ciliata in combination with honey has been used by post-partum women against the gastrointestinal disorders. Its rhizome has also been used by adults as an anti-helimintic. Boiled roots of Bergenia ciliata in combination with salt have been reported to be used for the cure of asthma. Its use for the treatment and prevention of piles and cancer is also reported $[7,19,20]$.

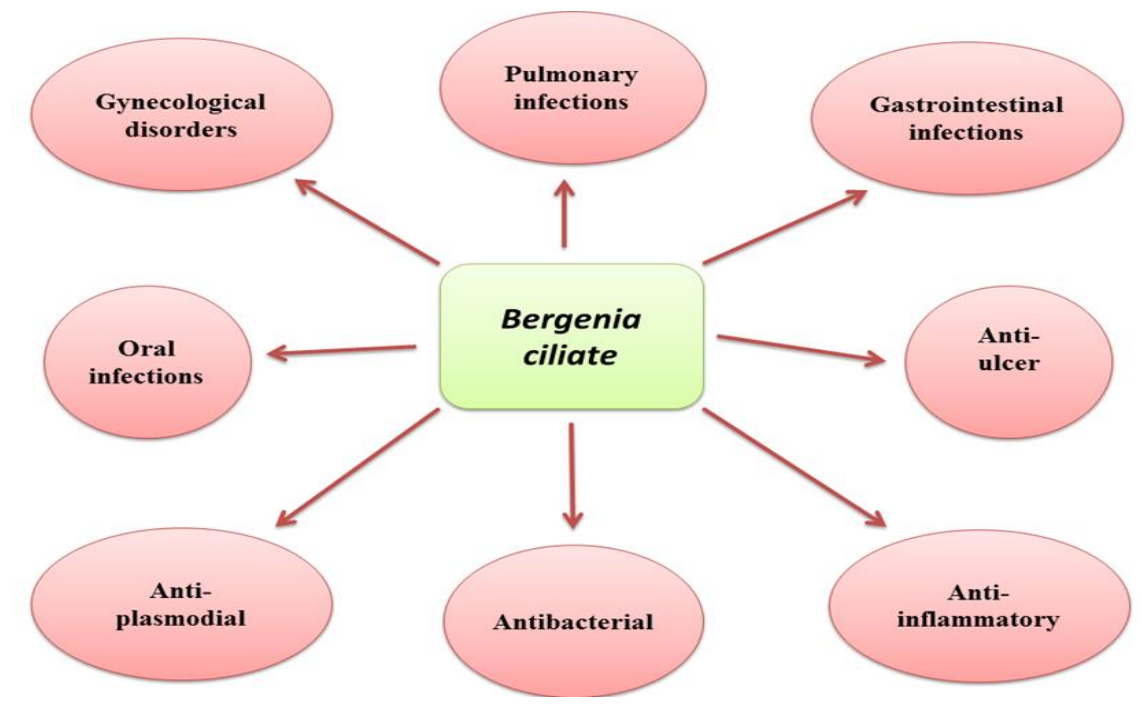

Figure 1 Some important traditional uses of Bergenia ciliata 


\section{Phytochemistry of Bergenia ciliata}

Bergenia ciliata is an important medicinal herbal plant that contains many important bioactive compounds. Many researchers have evaluated various phytochemicals from Bergenia ciliata (Figure 2; Figure 3). Generally there are about 58 phytochemicals present in Bergenia ciliata species of which 48 volatile organic compounds are categorized into 11 categories viz; alcohols, fatty acids, phenols, carboxylic acids, terpenoids, flavonoids, glycosides, nitro compounds, sterol, cinnamic acid and volatile organic compounds [10]. Some of the important classes of compounds along with their IUPAC names and general formula isolated from Bergenia ciliata are given in Table 1.<smiles>[CH2-][C@@]12OC(=O)c3cc(O)c(OC)c(O)c3[C@@]1(C)O[C@H](O)[C@@H](O)[C@@H]2O</smiles>

1<smiles>O=C(O)c1cc(O)c(O)c(O)c1</smiles>

2<smiles>CC1=CCC(O)(C(C)C)CC1</smiles>

Figure 2 Chemical structures of compounds 1-5 isolated from Bergenia ciliata. 
Table 1 Some important phytochemicals isolated from Bergenia ciliata.

\begin{tabular}{|c|c|c|c|c|}
\hline S. No. & Phytochemicals & IUPAC names & General formula & Ref. \\
\hline \multicolumn{5}{|c|}{ Phenolic contents } \\
\hline 1 & Bergenin & $\begin{array}{l}(2 \mathrm{R}, 3 \mathrm{~S}, 4 \mathrm{~S}, 4 \mathrm{aR}, 10 \mathrm{bS})-3,4,8,10 \text {-tetrahydroxy-2-(hydroxymethyl)-9- } \\
\text { methoxy-3,4,4a,10b-tetrahydro-2H-pyrano[3,2-c]isochromen-6-one }\end{array}$ & $\mathrm{C}_{14} \mathrm{H}_{16} \mathrm{O}_{9}$ & {$[21]$} \\
\hline 2 & Gallic acid & 3,4,5-Trihydroxybenzoic acid & $\mathrm{C}_{6} \mathrm{H}_{2}(\mathrm{OH})_{3} \mathrm{COOH}$ or $\mathrm{C}_{7} \mathrm{H}_{6} \mathrm{O}_{5}$ & {$[20]$} \\
\hline 3 & Tannic acid & $\begin{array}{l}\text { [2,3-dihydroxy-5-[[(2R,3R,4S,5R,6S)-3,4,5,6-tetrakis[[3,4-dihydroxy-5- } \\
\text { (3,4,5-trihydroxybenzoyl) } \quad \text { oxybenzoyl }] \text { oxy }] \\
\text { yl]methoxycarbonyl]phenyl] } 3,4,5 \text {-trihydroxybenzoate }\end{array}$ & $\mathrm{C}_{76} \mathrm{H}_{52} \mathrm{O}_{46}$ & {$[22]$} \\
\hline \multicolumn{5}{|c|}{ Alcohols } \\
\hline 4 & 3-Pentanol & 3-Pentanol & $\mathrm{C}_{5} \mathrm{H}_{12} \mathrm{O}$ & {$[23]$} \\
\hline 5 & Terpinen-4-ol & Terpinen-4-ol & $\mathrm{C}_{10} \mathrm{H}_{18} \mathrm{O}$ & {$[24]$} \\
\hline 6 & Pentanol & Pentan-1-ol & $\mathrm{C}_{8} \mathrm{H}_{18} \mathrm{O}$ & [7] \\
\hline \multicolumn{5}{|c|}{ Flavonoids } \\
\hline 7 & $(+)$-Afzelechin & (2R,3S)-2-(4-hydroxyphenyl)-3,4-dihydro-2H-chromene-3,5,7-triol & $\mathrm{C}_{15} \mathrm{H}_{14} \mathrm{O}_{5}$ & [25] \\
\hline 8 & $\begin{array}{l}\text { Quercetin 3-o- } \alpha-\mathrm{L}- \\
\text { arbinofuranoxide }\end{array}$ & $\begin{array}{l}\text { 3-[(2S,3R,4R,5S)-3,4-dihydroxy-5-(hydroxymethyl)oxolan-2-yl]oxy-2- } \\
\text { (3,4-dihydroxyphenyl)-5,7-dihydroxychromen-4-one }\end{array}$ & $\mathrm{C}_{20} \mathrm{H}_{18} \mathrm{O}_{11}$ & {$[26]$} \\
\hline \multicolumn{5}{|c|}{ Fatty acids } \\
\hline 9 & $\begin{array}{l}\text { 2-Methyl butanoic } \\
\text { acid }\end{array}$ & 2-Methyl butanoic acid & $\mathrm{C}_{5} \mathrm{H}_{10} \mathrm{O}_{2}$ & {$[27]$} \\
\hline 10 & Decanoic acid & Decanoic acid & $\mathrm{C}_{10} \mathrm{H}_{20} \mathrm{O}_{2}$ & {$[28]$} \\
\hline 11 & Nonanoic acid & Nonanoic acid & $\mathrm{C}_{9} \mathrm{H}_{18} \mathrm{O}_{2}$ & [27] \\
\hline \multicolumn{5}{|c|}{ Terpenoids } \\
\hline 12 & Camphor & 1,7,7-Trimethylbicyclo[2.2.1]heptan-2-one & $\mathrm{C}_{10} \mathrm{H}_{16} \mathrm{O}$ & [29] \\
\hline 13 & Glucoside & 4,11,11-trimethyl-8-methylene-bicyclo[7.2.0]undec-4-ene & $\mathrm{C}_{15} \mathrm{H}_{24}$ & [7] \\
\hline \multicolumn{5}{|c|}{ Terpenes } \\
\hline 14 & Linalool & 3,7-dimethylocta-1,6-dien-3-ol & $\mathrm{C}_{10} \mathrm{H}_{18} \mathrm{O}$ & {$[30]$} \\
\hline 15 & Beta-phellandrene & 3-methylidene-6-propan-2-ylcyclohexene & $\mathrm{C}_{10} \mathrm{H}_{16}$ & {$[31]$} \\
\hline
\end{tabular}


<smiles>CCCCCO</smiles>

6<smiles>O=c1c(OC2OC[C@H]3OC[C@@H]2[C@H]3O)c(-c2ccc(O)c(O)c2)oc2cc(O)cc(O)c12</smiles><smiles>CCC(=O)O</smiles>

10

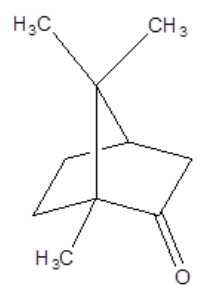

12<smiles>Oc1ccc([C@@H]2Oc3cc(O)cc(O)c3C[C@H]2O)cc1</smiles><smiles>CCC(C)C(=O)O</smiles>

9

11

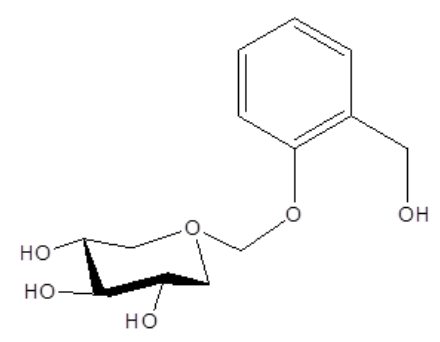

13

14<smiles>C=C1C=CC(C(C)C)CC1</smiles>

Figure 3 Chemical structures of compounds 6-15 isolated from Bergenia ciliata.

\section{Bergenia ciliata as antibacterial agent}

The renewed interest of researchers in medicinal plants allowed them to investigate medicinal plants, such as Bergenia ciliata, and search new strategies and substances to combat infectious diseases. Several pharmacological studies reported that Bergenia ciliata is a potent antibacterial agent (Table 2). In present study we have reviewed different extracts of Bergenia ciliata that can be used against pathogenic bacteria. The antibacterial activities of three medicinal plants including Bergenia ciliata have been investigated. The acetone extracts of the plants showed remarkable anti- 
inhibitory effect against three pathogens, namely Escherichia coli, Bacillus subtilis and Pseudomonas aeruginosa [30]. It was published that rhizome extracts (in methanol, ethanol, water and n-hexane) of Bergenia ciliata showed significant antibacterial potential against four bacterial strains; Klebsiella pneumonia, Staphylococcus auereus, Bacillus subtilis and Escherichia coli. Among all the extracts the methanolic extract showed greater inhibitory potential (12.9 \pm 0.5 to $11.8 \pm 0.7 \mathrm{~mm}$ ) while the lowest inhibition was showed by aqueous fraction $(4.5 \pm 0.3$ to $3.5 \pm 0.1 \mathrm{~mm})$ [32]. Another study reported that ethanolic rhizome extracts of Bergenia ciliata showed remarkable antibacterial activities against selected pathogens Salmonella typhimurium (inhibition zone $12 \pm 1.0 \mathrm{~mm}$ ) and Escherichia coli (inhibition zone $11.33 \pm 0.57 \mathrm{~mm}$ ) [33]. The ethanolic, chloroform, butanolic, hexane, ethyl acetate and aqueous roots and leaves extracts of Bergenia ciliata were evaluated for their antibacterial inhibitory activity against Gram positive and Gram negative strains viz; Staphylococcus auereus, Bacillus subtilis, micrococcus and Bacillus megalerium. It was observed from the results that root extracts of Bergenia ciliata have higher antibacterial activities as compared to the leaves extracts [34]. The antibacterial activities of callus extracts of Bergenia ciliata were determined against selected pathogens viz; Pseudomonas aeruginosa, Staphylococcus aureus, Pseudomonas aeruginosa, Pseudomonas aeruginosa, Staphylococcus aureus and Pseudomonas aeruginosa [35]. The methanol, ethyl acetate and hexane extracts of Bergenia ciliata were evaluated against the selected bacterial strains including Nocardia tenerifensis, Bacillus megaterium and Bacillus subtilis. Among all the extracts the methanolic extract was found to have better antibacterial potential [20]. The antibacterial potential of the crude extract of Bergenia ciliata was determined against six bacterial strains including Bordetella bronchiseptica, Salmonella Setubal, Escherichia coli, Micrococcus luteus, Staphylococcus aureus and Salmonella typhimurium. The results showed that the crude extract significantly inhibited all the selected pathogens [36]. In vitro ethanolic, hexane, distilled water and butanolic extracts of Bergenia ciliata also showed significantly antibacterial activities against Escherichia coli, Staphylococcus aureus, Pseudomonas aeruginosa and Streptococcus faecalis bacteria [37]. Leaves extracts of Bergenia ciliata showed significant antibacterial potential against Staphylococcus aureus and Bacillus megaterium with an inhibition zone of 8-12 mm and 10-20 mm respectively [38]. Another study also evaluated the antibacterial potential of ethanolic extracts of Bergenia ciliata against seven selected bacteria including Bacillus subtilis, Klebsiella pneumonia, Staphylococcus aureus, Escherichia coli, Salmonella typhi, Shigella dysentriae and Sacchromyces cerevisiae with the inhibition zone $22.8 \pm 0.15 \mathrm{~mm}, 18.6 \pm 0.15 \mathrm{~mm}, 24.0 \pm 0.10 \mathrm{~mm}, 23.7 \pm 0.25 \mathrm{~mm}, 22.8 \pm 0.15 \mathrm{~mm}, 29.4 \pm 0.47 \mathrm{~mm}$ and $23.4 \pm 0.26 \mathrm{~mm}$ respectively [39].

Table 2 Antibacterial activities of Bergenia ciliata.

\begin{tabular}{|c|c|c|}
\hline Extract & Susceptible bacteria & Ref. \\
\hline Acetone extract & Escherichia coli, Bacillus subtilis and Pseudomonas aeruginosa & {$[30]$} \\
\hline $\begin{array}{l}\text { Methanol, ethanol, water and n- } \\
\text { hexane extracts }\end{array}$ & $\begin{array}{l}\text { Klebsiella pneumonia, Staphylococcus auereus, Bacillus subtilis and } \\
\text { Escherichia coli }\end{array}$ & [32] \\
\hline Ethanol extract & Salmonella typhimurium and Escherichia coli & {$[33]$} \\
\hline $\begin{array}{l}\text { Ethanol, chloroform, butanol, } \\
\text { hexane, ethyl acetate and aqueous } \\
\text { extracts }\end{array}$ & $\begin{array}{l}\text { Staphylococcus auereus, Bacillus subtilis, micrococcus and Bacillus } \\
\text { megalerium }\end{array}$ & [34] \\
\hline Callus extract & $\begin{array}{l}\text { Pseudomonas aeruginosa, Staphylococcus aureus, Pseudomonas } \\
\text { aeruginosa, Pseudomonas aeruginosa, Staphylococcus aureus and } \\
\text { Pseudomonas aeruginosa }\end{array}$ & [35] \\
\hline $\begin{array}{l}\text { Methanol, ethyl acetate and } \\
\text { hexane extracts }\end{array}$ & Nocardia tenerifensis, Bacillus megaterium and Bacillus subtilis & {$[20]$} \\
\hline Crude extract & $\begin{array}{l}\text { Bordetella bronchiseptica, Salmonella Setubal, Escherichia coli, } \\
\text { Micrococcus luteus, Staphylococcus aureus and Salmonella typhimurium }\end{array}$ & {$[36]$} \\
\hline $\begin{array}{l}\text { Ethanol, hexane, distilled water } \\
\text { and butane extracts }\end{array}$ & $\begin{array}{l}\text { Escherichia coli, Staphylococcus aureus, Pseudomonas aeruginosa and } \\
\text { Streptococcus faecalis }\end{array}$ & [37] \\
\hline Leaves extracts & Staphylococcus aureus and Bacillus megaterium & {$[38]$} \\
\hline Ethanol extract & $\begin{array}{l}\text { Bacillus subtilis, Klebsiella pneumonia, Staphylococcus aureus, } \\
\text { Escherichia coli, Salmonella typhi, Shigella dysentriae and Sacchromyces } \\
\text { cerevisiae }\end{array}$ & [39] \\
\hline
\end{tabular}




\section{Conclusion}

The present study gathers the fragmented literature about the antibacterial potential of Bergenia ciliata. The phytochemicals present in of Bergenia ciliata exhibit various biological activities including antibacterial, antioxidants, antifungal, antihaemolytic and cytotoxic. This mini-review would be beneficial for researchers in future to study the medicinally important constituents of Bergenia ciliata to develop new drugs that can be used to combat the antibioticresistant pathogens. Based on current review, Bergenia ciliata is considered is one of the most important antibacterial agent which attributed to its phytochemical constituents but some of the constituents of Bergenia ciliata has adverse effects on human health. Therefore, in-depth and intensive studies are required in order to isolate the antibacterial molecules and evaluate the safety, dosage and possible side effects.

\section{Compliance with ethical standards}

\section{Acknowledgments}

We would like to thank our elder brothers Said Iftikhar Ali Shah, Mohammad Halim and Muhammad Saleem for their encouragement, moral support, personal attention and care.

\section{Disclosure of conflict of interest}

All the authors declare that they have no conflict of interest.

\section{References}

[1] Khan I, Najeebullah, Ali SM and Shinwari ZK. (2016). Phytopharmacological and ethnomedicinal uses of the Genus Berberis (Berberidaceae): A review. Tropical Journal of Pharmaceutical Research, 15(9), 2047-2057.

[2] Verma SK, Gond SK, Mishra A, SharmaVK, Kumar J, Singh DK, Kumar A and Kharwar RN. (2017). Fungal endophytes representing diverse habitats and their role in plant protection. Developments in Fungal Biology and Applied Mycology, 135-157.

[3] Deák B, Valkó O, Török P, Kelemen A, Bede A, Csathó AI and Tóthmérész B. (2018). Landscape and habitat filters jointly drive richness and abundance of specialist plants in terrestrial habitat islands. Landscape Ecology, 33(7), 117-1132.

[4] Tungmunnithum D, Thongboonyou A, Pholboon A and Yangsabai A. (2018). Flavonoids and other phenolic compounds from medicinal plants for pharmaceutical and medical aspects: An overview. Medicines, 5(3), 93.

[5] Ambasta SK, Kumari S, yadav AK, Trivedi I, Prasad B and Sinha UK. (2016). Medicinal plants of Bihar and its neighboring region which needs attention for their conservation. European Journal of Biomedical and Pharmaceutical Sciences, 3(4), 544-55.

[6] Majolo F, Delwing LKdOB, Marmitt DJ, Bustamante-Filho IC and Goettert MI. (2019). Medicinal plants and bioactive natural compounds for cancer treatment: Important advances for drug discovery. Phytochemistry Letters, 31(4), 196-207.

[7] Ahmad M, Butt MA, Zhang G, Sultana S, Tariq A and Zafar M. (2018). Bergenia ciliata: A comprehensive review of its traditional uses, phytochemistry, pharmacology and safety. Biomedicine and Pharmacotherapy, 97(5), 708721.

[8] Żbikowska B, Franiczek R, Sowa A, Połukord G, Krzyzanowska B and Sroka Z. (2017). Antimicrobial and Antiradical Activity of Extracts Obtained from Leaves of Five Species of the Genus Bergenia: Identification of Antimicrobial Compounds. Microbial Drug Resistance, 23(6), 771-780.

[9] Timalsena S and Lamichhane PP. (2019). Astible Rivularis: Bioactive Compounds and Pharmacological Functions. Chinese Journal of Integrative Medicine, 25(10), 795-799.

[10] Hussain A, Kanth M, Shrivastva PK, Sharma M, Tripath J and Khan MA. (2019). Phytochemical analysis of the rhizomes of Bergenia ciliata (How) Sternb. Journal of Drug Delivery and Therapeutics, 9(3), 412-416.

[11] Phull A-R, Abbas Q, Ali A, Raza H, kim S-J, Zia M and Ul-haq I. (2016). Antioxidant, cytotoxic and antimicrobial activities of green synthesized silver nanoparticles from crude extract of Bergenia ciliata. Future Journal of Pharmaceutical Sciences, 2(1), 31-36. 
[12] Tiwari V, Meena B, Nair NK and Rana TS. (2020). Molecular analyses of genetic variability in the populations of Bergenia ciliata in Indian Himalayan Region (IHR). Physiology and Molecular Biology of Plants, 26(5), 975-984.

[13] Zafar R, Ullah H, Zahoor M and Sadiq A. (2019). Isolation of bioactive compounds from Bergenia ciliata (haw.) Sternb rhizome and their antioxidant and anticholinesterase activities. BMC Complementary and Alternative Medicine, 19(1) 1-13.

[14] González-Bello C. (2017). Antibiotic adjuvants - A strategy to unlock bacterial resistance to antibiotics. Bioorganic and Medicinal Chemistry Letters, 27(18), 4221-4228.

[15] Catteau L, Zhu L, Bambeke FV and Quetin-Leclercq J. (2018). Natural and hemi-synthetic pentacyclic triterpenes as antimicrobials and resistance modifying agents against Staphylococcus aureus: a review. Phytochemistry Reviews, 17(5), 1129-1163.

[16] Barker WT, Chandler CE, Melander RJ, Ernst RK and Melander C. (2019). Tryptamine derivatives disarm colistin resistance in polymyxin-resistant gram-negative bacteria. Bioorganic and Medicinal Chemistry, 27(9), 17761788.

[17] Martens E and Demain AL. (2017). The antibiotic resistance crisis, with a focus on the United States. Journal of Antibiotics, 70(5), 520-526.

[18] Ganesan P and Pradeepa P. (2017). Development and characterization of nanofibrous mat from PVA/Tridax Procumbens (TP) leaves extracts. Wound Medicine, 19(3), 15-22.

[19] Saha S, Shrivastav PS and Verma RJ. (2014). Antioxidative mechanism involved in the preventive efficacy of Bergenia ciliata rhizomes against experimental nephrolithiasis in rats. Pharmaceutical Biology, 52(6), 712-722.

[20] Singh M, Pandey N, Agnihotri V, Singh KK and Pandey A. (2017). Antioxidant, antimicrobial activity and bioactive compounds of Bergenia ciliata Sternb: A valuable medicinal herb of Sikkim Himalaya. Journal of Traditional and Complementary Medicine, 7(2), 152-157.

[21] Chauhan R, Ruby KM and Dwivedi J. (2013). Secondary metabolites found in Bergenia species: A compendious review. International Journal of Pharmacy and Pharmaceutical Sciences, 5(1), 9-16.

[22] Walter NS, Bagai U and Kalia S. (2013). Antimalarial activity of Bergenia ciliata (Haw.) Sternb. against Plasmodium berghei. Parasitology Research, 112(9), 3123-3128.

[23] Gyawali R and Kim K-S. (1970). Bioactive volatile compounds of three medicinal plants from Nepal. Kathmandu University Journal of Science, Engineering and Technology, 8(1), 51-62.

[24] Engl T, Kumar P, Javed MS, Tewari AK and Bisht KS. (2017). Phytochemical investigation and in vitro antifungal activity of essential oil from the rhizome of Bergenia stracheyi (Hook.f. \& Thomson) Engl. Journal of Drug Delivery and Therapeutics, 7(1), 37-43.

[25] Dhalwal K, Shinde VM, Biradar YS and Mahadik KR. (2008). Simultaneous quantification of bergenin, catechin, and gallic acid from Bergenia ciliata and Bergenia ligulata by using thin-layer chromatography. Journal of Food Composition and Analysis, 21(6), 496-500.

[26] Kumar V and Tyagi D. (2013). Review on phytochemical, ethnomedical and biological studies of medically useful genus Bergenia. International Journal of Current Microbiology and Appied Sciences, 2(5), 328-334.

[27] Kour H, Raina R, Verma PK, Pankaj NK and Singh SP. (2019). Phytochemical ingredients and pharmacological properties of Bergenia ciliata. Journal of Veterinary Pharmacology and Toxicology, 18(1), 1-10.

[28] Shirsat VA, Dhainje VM, Krishnapriya M and Ghone S. (2018). Identification of potential antioxidants by in-vitro activity guided fractionation of Bergenia ligulata. Pharmacognosy Magazine, 4(15), 78-84.

[29] Nasreen S, Safeer S, Dar KK, Andleeb S, Ejaz M, Khan MA and Ali S. (2018). Etiology of hepatocellular carcinoma and treatment through medicinal plants: a comprehensive review. Oriental Pharmacy and Experimental Medicine, 18(3), 187-197.

[30] Shankar KG, Fleming AT, Vidhya R and Pradhan N. (2016). Synergistic efficacy of three plant extracts, Bergenia ciliata, Acorus calamus and Dioscorea bulbifera for antimicrobial activity. International Journal of Pharma and Bio Sciences, 7(4), 619-628.

[31] Byahatti VV, Pai KV and D’Souza MG. (2010). Effect of Phenolic Compounds from Bergenia ciliata (Haw.) Sternb. leaves on Experimental kidney stones. Ancient science of life, 30(1), 14-7. 
[32] Yousaf S, Kaukab G, Gul H, Khalid N, Kausar R, Ahmed H, Ajab H and Gulfraz M. (2018). Pharmacological and phytochemical analysis of Bergenia ciliata leaf and rhizome extracts. Pakistan Journal of Pharmaceutical Sciences, 31(5), 1911-1916.

[33] Verma R, Tapwal A, Kumar D and Puri S. (2019). Assessment of antimicrobial potential and phytochemical profiling of ethnomedicinal plant Bergenia ciliata (Haw.) Sternb. In Western Himalaya. Journal of Microbiology, Biotechnology and Food Sciences, 9(1), 15-20.

[34] Pokhrel P, Parajuli RR, Tiwari AK and Banerjee J. (2014). A short glimpse on promising pharmacological effects of Begenia ciliata. Journal of Applied Pharmaceutical Research, 2(1), 1-6.

[35] Khan UA, Rahman H2, Niaz Z, Qasim M, Khan J, Tayyaba and Rehman B. (2013). Antibacterial activity of some medicinal plants against selected human pathogenic bacteria. European Journal of Microbiology and Immunology, 3(4), 272-274.

[36] Ahmed M, Phul AR, Ihsan-ul-Haq, Bibi G, Mazhar K, Ur-Rehman T, Zia M and Mirza B. (2016). Antioxidant, anticancer and antibacterial potential of Zakhm-e-hayat rhizomes crude extract and fractions. Pakistan Journal of Pharmaceutical Sciences, 29(3), 895-902.

[37] Pokhrel P, Banerjee J, Dahal P, Khanal H, Gupta AK and Dey BK. (2014). Phytochemical Screening and Biological Evaluation of Different Parts of Plant Bergenia ciliata. Journal of Pharmacognosy and Phytochemistry, 3(4), 220224.

[38] Rajbhandari M, Mentel R, Jha PK, Chaudhary RP, Bhattarai S, Gewali MB, Karmacharya N, Hipper M and Lindequist U. (2009). Antiviral Activity of Some Plants Used in Nepalese Traditional Medicine. Evidence-Based Complementary and Alternative Medicine, 6(4), 517-522.

[39] Khan N, Abbasi AM, Dastagir G, Nazir A, Shah GM, Shah MM and Shah MH. (2014). Ethnobotanical and antimicrobial study of some selected medicinal plants used in Khyber Pakhtunkhwa (KPK) as a potential source to cure infectious diseases. BMC Complementary and Alternative Medicine, 14, 1-10.

\section{How to cite this article}

Shah SS, Shah D, Khan I, Ilyas M, Jan SA and Khan I. (2020). Bergenia ciliata as antibacterial agent. GSC Biological and Pharmaceutical Sciences, 12(2), 37-45. 